Received 12.06.2017 Reviewed 28.07.2017 Accepted 07.08.2017

A - study design

B - data collection

C - statistical analysis

D - data interpretation

E - manuscript preparation

F - literature search

\section{Evaluation of the effects of land consolidation in the Latyczyn village in terms of land protection against erosion on the slope scale}

\author{
Roman RYBICKI ${ }^{\mathrm{ABCDEF} \bowtie}$
}

University of Life Sciences in Lublin, Faculty of Production Engineering, Department of Environmental Engineering and Geodesy, ul. Leszczyńskiego 7, 20-069 Lublin, Poland; e-mail: roman.rybicki@up.lublin.pl

For citation: Rybicki R. 2017. Evaluation of the effects of land consolidation in the Latyczyn village in terms of land protection against erosion on the slope scale. Journal of Water and Land Development. No. 35 p. 203-209. DOI: 10.1515/jwld-2017-0085.

\begin{abstract}
Soil erosion by water is an important economical issue strongly deteriorating environment and requiring remedial actions. The study was designed to evaluate antierosion effect of changes in the layout of plots from along to across slope as an effect of land consolidation. Moreover, rightness of leaving newly set out boundaries of plots without any protection (i.e. sodding) was evaluated. For this purpose simulations of use of additional anti-erosive measures were done. The Water Erosion Prediction Project (WEPP) model was used. Studies have shown that in addition to the design of transverse layout of parcels during consolidation, further antierosion measures may be necessary to reduce soil loss and sediment yield. In order to minimize soil losses outside the slope, boundaries between the newly designed fields should be sodded already in the post consolidation management. Limitation the amount of erosion over the entire slope requires use of additional protection measures in the upper part of slopes e.g. shelterbelts and antierosion crop rotations. WEPP model can be recommended for Provincial Bureaus of Surveying as a tool to support the development of assumptions for consolidation projects of lands threatened by erosion.
\end{abstract}

Key words: land consolidation, prediction of erosion, soil erosion, upland areas, WEPP model

\section{INTRODUCTION}

Upland areas located in the south-eastern part of Poland, due to the high potential production of soils are classified as areas of intensive agriculture. However, there are many negative factors in this area that limits agricultural production. The most important are surface water erosion and gully erosion that resulting in soil degradation, deformation of water relations and diversification of potential of soil production [JÓZEFACIUK, JÓZEFACIUK 1995]. In addition, occurring large fragmentation, dispersion and mutual chessboard of lands, makes that plots are difficult to farming and the efficiency of agriculture is reduced. For this reason, also eroded areas needs land consolidation. Because of the varied relief of terrain - occurrence of inner-slope valleys and slopes with different exposures, suffusion drench and other erosion waste- land, the project of land consolidation can be extremely difficult. At the same time, land fragmentation and the occurrence of balks and scarps, trees, sods and mosaics of crops, makes that the intensification of water erosion is limited. Therefore, land consolidation in such areas besides of enlargement of plots must also take into account the principles of protection of the land against erosion [JÓZEFACIUK et al. 1991; NogA, PIJANOWSKI 1993; WOCH, JÓZEFACIUK 1999]. Land consolidation conducted in the traditional way (only with enlargement of plots and at the same time liquidation of anti-erosion protections shaped by the centuries-old crop) may cause erosion processes with damage greater than the benefits of consolidation [JÓZEFACIUK et al. 1991; KORELESKI 1987; WOCH 2008]. This is also shown by the results of foreign research [BRONSTERT et al. 1995; CHARTIN et al. 2013]. 
At the end of the twentieth century, Institute of Soil Science and Plant Cultivation (Pol. Instytut Uprawy Nawożenia i Gleboznawstwa - IUNG) Puławy developed concepts of complex consolidation of heavily undulated lands [JÓZEFACIUK et al. 1992; WOCH, JÓZEFACIUK 1996; 1999]. It has been proven that apart from positive economic and spatial effects of classical merge works it is also possible to obtain the positive natural and ecological effects. They expressed the improvement of microclimate and landscape conditions and a significant decrease of the intensity of soil erosion [WOCH 1994]. Similar positive environmental effects of land consolidations are also noted in foreign literature [KONEČNÁ et al. 2012; LISEC, PInTAR 2005; ShUAI et al. 2011]. Despite the positive results of the implementation work, the Regional Bureau of Geodesy in Lublin does not currently perform complex consolidations works and classical consolidation works are concentrated mainly in flat areas. However, some of the objects located in the high differentiated relief areas were also included to the consolidation.

One of the objects located in the high differentiated relief areas is Latyczyn in Western Roztocze. The assumptions for the land consolidation project, apart from the improvement of economic and spatial conditions also included antierosion measures. In addition to the strengthening of agricultural transport roads, these measures also included the adaptation of new boundaries of plots to relief [JABLOŃSKI 2012]. The aim of the study is to evaluate the effect of changes in the layout of plots from along to across slope on the intensity of water erosion of soils at the single slope scale. Moreover, rightness of leaving newly set out the boundaries of plots without use of any antierosion means (e.g. sodding) was evaluated. Therefore, an additional simulations of the use of different antierosive measures was made to assess their effectiveness at the protection of soil against erosion and compare them with the current conditions of tested slope.

\section{RESEARCH METHODS AND STUDY AREA}

The study area - Latyczyn village (with an area of 972.85 ha) is located in Radecznica municipality, Zamość district. Land consolidation was conducted in the years 2012-2014. Whole object is located in West Roztocze in the area of Szczebrzeszyn Landscape Park and should be considered as typical for this region. There is a very diverse relief reaching the height differences of $100 \mathrm{~m}$. Hills are crossed by numerous well-developed gullies. Over $80 \%$ of the area is occupied by soils made from deep loess. Because of the type of the soils and the slope of land which exceeds even $20 \%$ and the type of climate (cold winters with the rapid thawing of snow and warm dry summers with heavy rain) about $25 \%$ of the area is threatened by medium to strong grade of water erosion (on the basis of JÓZEFACIUK and JÓZEFACIUK [1995]). Mean annual temperature is $7.4^{\circ} \mathrm{C}$ and annual precipitation is approximately $561 \mathrm{~mm}$ [weatheronline.pl undated].
Soil organic matter content is $1.53 \%$ and bulk density of $1.58 \mathrm{Mg} \cdot \mathrm{m}^{-3}$ with $11 \%$ clay content $(<0.002 \mathrm{~mm})$. Land use structure is typical for Roztocze. Arable land constitutes $60 \%$ of the area, grassland occupies about $13 \%$ of the area and forests and woodlands represent $22 \%$ of total area.

Due to the occurrence of intensive water erosion, special attention has been paid to the protection of soils against erosion during the consolidation process. Existing in most part of the Latyczyn village contour layout of plots has been preserved during consolidation and the high balks with shrubs or shelterbelts also remained largely unbroken. At the same time, where the layout of the parcels was unfavorable (longitudinal) it was changed into across-slope (adapted to the principle of anti-erosion land development) [JABŁOŃSKI 2012].

In order to estimate erosion hazard and develop a comprehensive plan for soil and water conservation, it is essential to estimate runoff and soil loss resulting from different management practices [PAŁYS, MAZUR 2015]. Therefore, to effectively consolidate sloping land, management practices and slope modifications should be designed in advance and next implemented over a short period of time. Estimation of erosion and evaluation of variety of management scenarios without costly and time-consuming field tests are important to accomplish land consolidation projects [PIERI et al. 2007]. To evaluate the effects of different practices on soil erosion and to select the best ecological practices, simulation models can also be used. In this study, a WEPP model [FLANAGAN, LIVINGSTON 1995] was selected to assess the effects of land consolidation measures on soil erosion. The Water Erosion Prediction Project (WEPP) is a process based, parameter distributed and continuous simulation erosion prediction model developed by United States Department of Agriculture, Agricultural Research Service (USDA ARS). It is a continuous simulation model that is able to predict spatial and temporal distributions of net soil loss and deposition for a wide range of time periods and spatial scales. As a final result, the model estimates the average annual soil loss and sediment yield. At slope scale, soil loss means the detachment and movement of topsoil by flowing water, while sediment yield means the amount of material eroded from the land surface by runoff and delivered to a channel or a stream system [SINGH et al. 2011].

The subject of this study is a slope of the area of 2 ha (Fig. 1) with an average slope inclination of $8.5 \%$ (max $15.5 \%$ ). It was assumed that the climate inputs were unchangeable and the only variables affecting soil erosion were slope conditions (management, terrain). Before consolidation, the layout of the parcels and the direction of cultivation was longitudinal - Figure 2a. As a result of consolidation, this system was changed into across-slope by dividing the slope into parcels of widths respectively $50,80,20,20,20$ and 16 meters from top to bottom - Figure $2 \mathrm{~b}$. The rightness of surveyors' decisions in terms of land protection against erosion was assessed and the simulation of using additional soil protection measures was made (Fig. 3). 


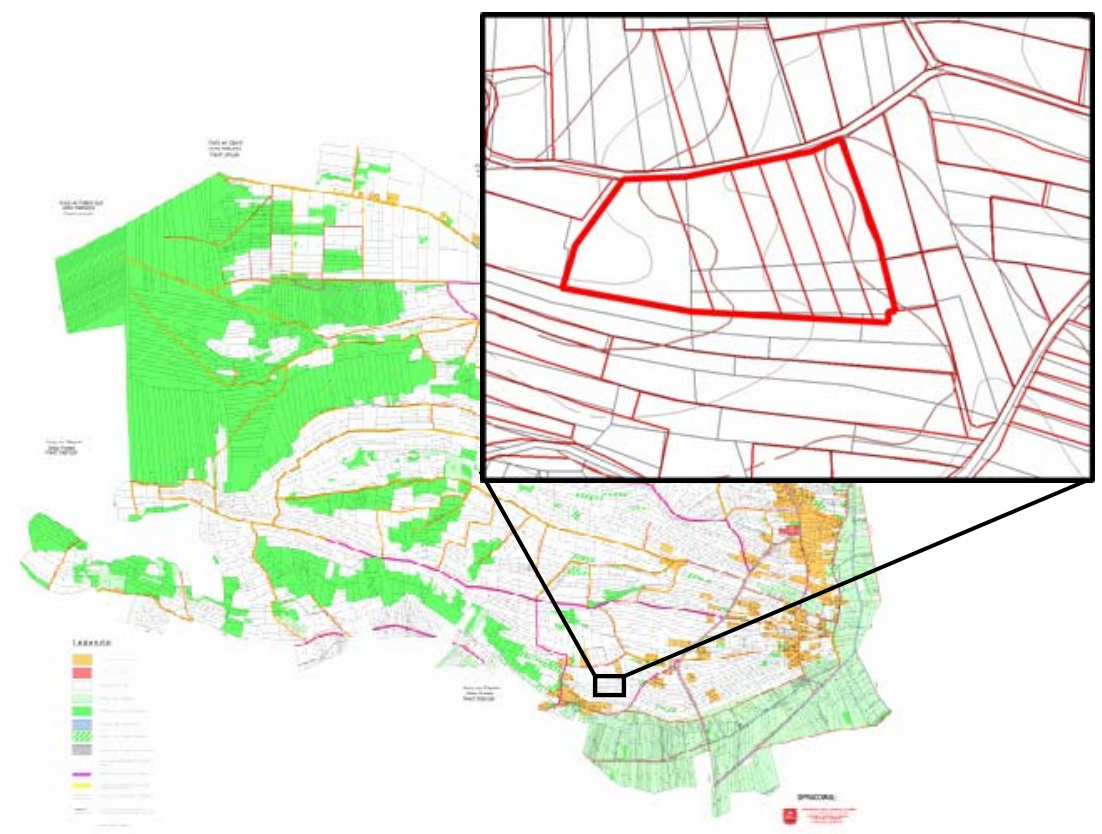

Fig. 1. Location of the study area; source: own elaboration based on map of assumption for the project of land consolidation made by the Provincial Bureau of Surveying in Lublin [JABŁOŃSKI 2012]

a)

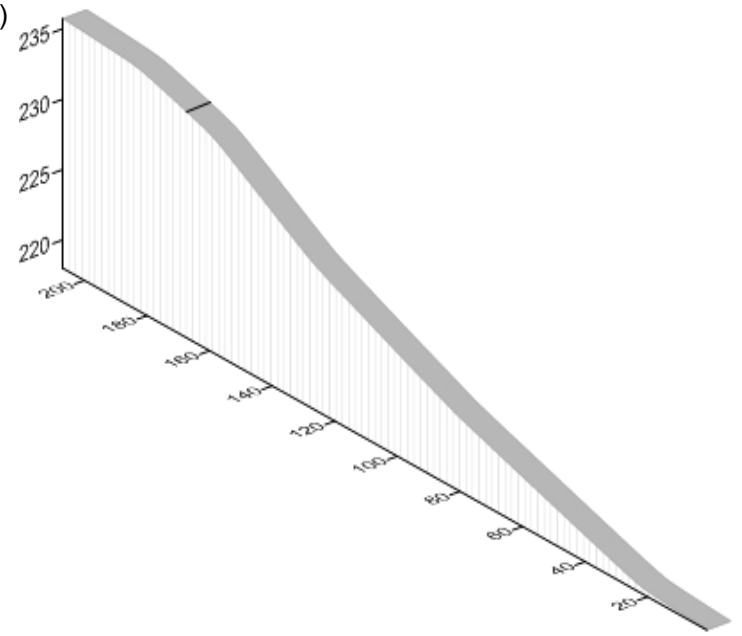

b)

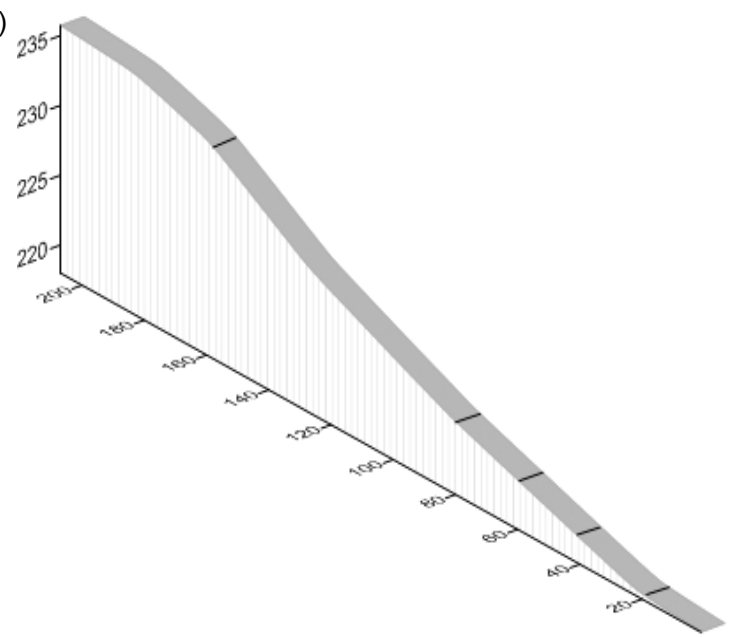

Fig. 2. Shape of slope and field boundary layout before (a) and after (b) consolidation; source: own elaboration
The following additional protection measures were simulated: sodding boundaries between fields, introducing a bush belt on the border of the fields 1 and 2 (counting from the top of the slope), division of second (the widest) field into two narrower and the use of alfalfa as antierosion crop in various fields on the slope (Fig. 3). Winter wheat in conventional crop was used as a basic crop. It is a main cereal crop in this region.

\section{RESULTS}

After modification of the slope management as a result of the rural management works, soil erosion processes were found to have changed greatly even before consolidation. The simulation results are summarized in Table 1, where the combinations of protection measures correspond to those in Figure 3.

Table 1. Predicted amounts of soil loss and sediment yield under different scenarios of slope management

\begin{tabular}{|c|c|c|}
\hline $\begin{array}{c}\text { Spatial combinations of slope } \\
\text { management }\end{array}$ & $\begin{array}{c}\text { Soil loss } \\
\mathrm{kg} \cdot \mathrm{m}^{-2}\end{array}$ & $\begin{array}{l}\text { Sediment yield } \\
\mathrm{Mg} \cdot \mathrm{ha}^{-1}\end{array}$ \\
\hline State before land consolidation A & 3.310 & 16.683 \\
\hline State after land consolidation B & 2.338 & 10.001 \\
\hline $\begin{array}{l}\text { Simulation of additional protection } \\
\text { measures }\end{array}$ & & \\
\hline B1 & 2.315 & 9.925 \\
\hline B2 & 2.289 & 8.019 \\
\hline B3 & 2.273 & 7.461 \\
\hline B4 & 2.210 & 9.379 \\
\hline B5 & 2.180 & 8.123 \\
\hline B6 & 2.160 & 8.045 \\
\hline B7 & 2.158 & 7.451 \\
\hline B8 & 1.934 & 8.224 \\
\hline B9 & 1.832 & 5.851 \\
\hline B10 & 1.468 & 6.122 \\
\hline B11 & 1.284 & 3.212 \\
\hline
\end{tabular}

Markings of combinations as shown in Fig. 3.

Source: own elaboration. 


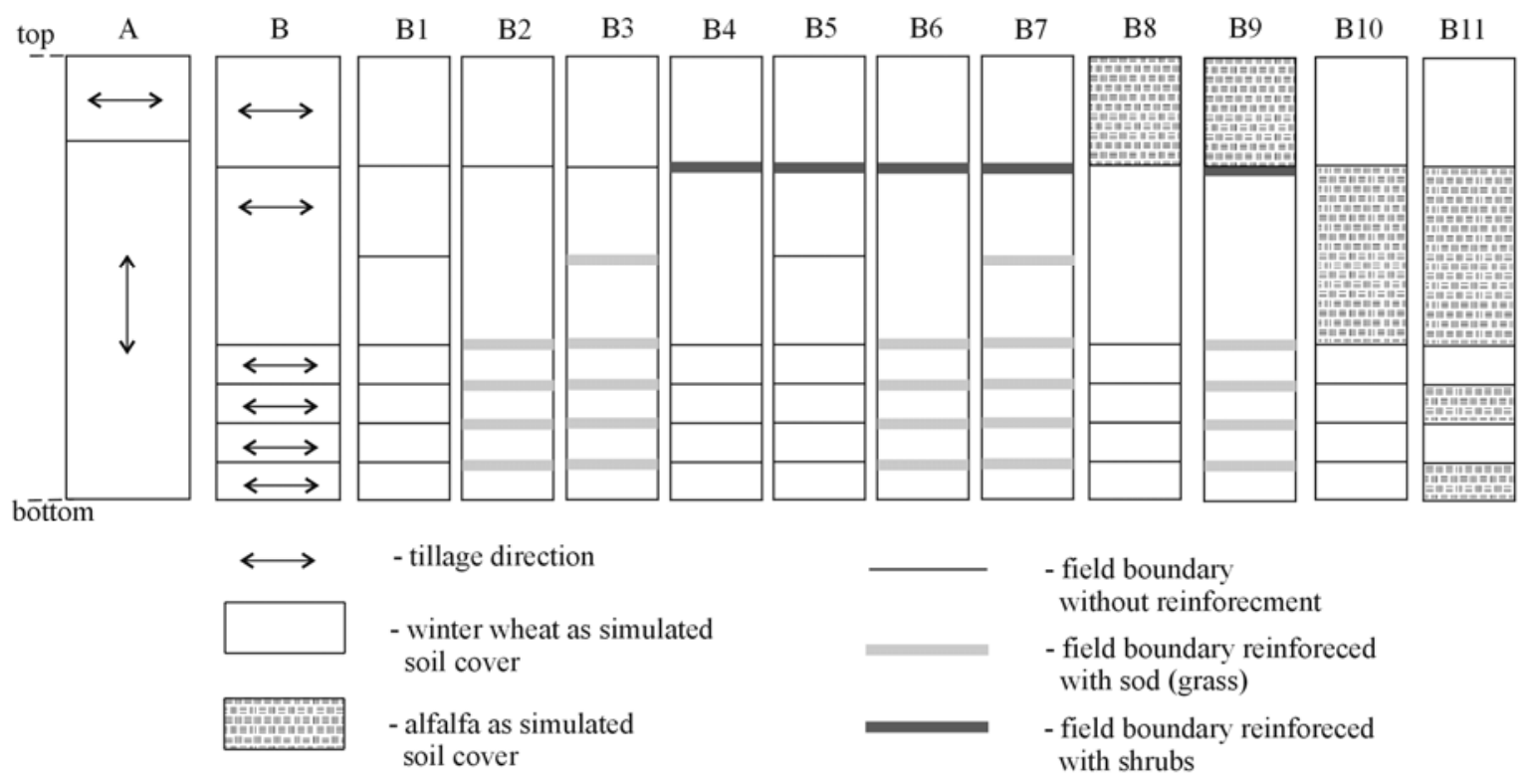

Fig. 3. Slope management before (A) and after (B) consolidation (shape of slope as in Figure 2) and spatial combinations of addition simulation of protection measures (B1-B11); source: own elaboration

Where prior to the consolidation, the slope was cultivated along the slopes and the crop was winter wheat, average annual soil loss as a result of erosion was $3.31 \mathrm{~kg} \cdot \mathrm{m}^{-2}$. In contrast, only after changing the layout of fields into transverse of slope ( 6 parcels were separated), the expected erosion decreased almost by $30 \%$ - to $2.38 \mathrm{~kg} \cdot \mathrm{m}^{-2}$. At the same time the sediment yield was reduced too. Prior to the consolidation, the average annual sediment yield was modelled as $16.683 \mathrm{Mg} \cdot \mathrm{ha}^{-1}$ while after consolidation, this amount was reduced to about $40 \%$ - to $10 \mathrm{Mg}$.

Since the second top plot is $80 \mathrm{~m}$ wide, according to the guidelines for designing optimal transverse plots [ZIEMNICKI 1967] is too wide, at first the effect of dividing it into two parcels with the width of $40 \mathrm{~m}$ was simulated. It turns out that if the new boundary will not be strengthened (the direction of cultivation remains transverse), its effect on soil loss reduction will be almost unnoticeable. Sediment yield is only slightly reduced. Additional reduction of erosion can be achieved by creation of obstacles to water run-off in the form of sodded boundaries - marking B3, Fig. 3 , Tab. 1. Simulation of the introduction of bounds with a width of about $0.3 \mathrm{~m}$ indicates a decrease in soil loss by another $2 \%$ in relation to the state before consolidation and about $13 \%$ reduction of sediment yield.

According to the recommendations for the management of eroded slopes, it is good practice to locate a linear plantings across slope in the upper part of the hill. It is supposed to dissipate surface runoff already in the top slopes so as to limit the risk of concentration of water flow in the lower slopes [PRZEGON et al. 2016; WEGGOREK 2008]. This treatment can bring a further reduction of soil loss from the slope by 0.1 $\mathrm{kg} \cdot \mathrm{m}^{-2}\left(1 \mathrm{Mg} \cdot \mathrm{ha}^{-1}\right)$, but the sediment yield, while absence of boundary protection in the lower slopes (B4), can only be $0.3 \mathrm{Mg}$ less than in the case of B1. While using all the borders strengthening as in the combination of B7, simulated soil loss would be $2.158 \mathrm{~kg} \cdot \mathrm{m}^{-2}$ ( $7 \%$ less in compare to the state after the consolidation, and about $35 \%$ less than before consolidation). The amount of sediment yield may decrease in this case to $7.451 \mathrm{Mg} \cdot \mathrm{ha}^{-1}$ (25\% less in compare to the state after the consolidation, and about $35 \%$ less than before consolidation).

Alfalfa is the field crop which is largely counteract the flow of water [ZIEMNICKI 1967]. Because the WEPP model also has in the databases this type of crop, simulations were made in order to assess the possibilities of improve of soil protection using this plant in crop rotation on various relief elements. It turned out that the effect of soil loss, when using alfalfa only on the first plot from the top, can be greater than the combined effect of applying protection on all of parcel boundaries. On the other hand, the effect of sediment yield reduction is smaller and comparable to the use of sodding only on the four lower boundaries of plots (B2). This is due to limiting rafting only in the upper part of the slope and the total absence of obstacles capturing the sediment yield (except transverse sowing) in the lower parts of the slope. If antierosion effect of growing of alfalfa would be combined with the strengthening of all boundaries of the parcels the amount of sediment yield would be reduced almost half compared to the current state after the consolidation and almost three times compared to the state before consolidation. Further simulations have shown that the introduction of alfalfa only to crop rotation on the widest plot - the second from the top (even without strengthening of boundaries) would further reduce soil loss up to $1.468 \mathrm{~kg} \cdot \mathrm{m}^{-2}$. However, in the case of B11, soil loss would be less than after consolidation by $45 \%$ and by $61 \%$ relative to the preconsolidation state. The amount of sediment yield would be reduced by $39 \%$ and $81 \%$, respectively. Fur- 
ther elimination of cereals in favour of alfalfa would cause even greater protection of soil. For example, if the alfalfa would be cultivated on the entire analysed slope, the soil loss would be $0.408 \mathrm{~kg} \cdot \mathrm{m}^{-2}$ and sediment yield $2.070 \mathrm{Mg} \cdot \mathrm{ha}^{-1}$.

\section{DISCUSSION}

Contour layout of plots and boundaries in sloped land is long considered as a very useful method for controlling erosion in rural landscapes [CHARTIN et al. 2013; JÓZEFACIUK, JÓZEFACIUK 1995; ZIEMNICKI 1967].

Highly differentiated relief areas with steep slopes are especially susceptible to water erosion [JÓZEFACIUK, JÓZEFACIUK 1995; ZIEMNICKI 1967]. However, the total amount of erosion is comprised of a number of other factors that relate both to characteristics of precipitation, soil, cover and use of the land, and morphology of catchment. Therefore, it seems that quantifying soil erosion dynamics is important for establishing the best design and management measures for land consolidation in short-term projects [WOCH 2008].

Research on water erosion conducted directly in the field are complicated and requires the installation of specialized equipment. Due to the high risks associated with the loss of washed soil material and the need for continuous monitoring of areas particularly vulnerable to erosion, there is a need to simulate the course of this process using models. Selection of the proper model should be preceded by a detailed analysis of the available data, specifying the size of the study area and the possibilities of simulation formulas, depending on the purpose of modelling.

Though several empirical and physical models such as Universal Soil Loss Equation (USLE), Revised Universal Soil Loss Equation (RUSLE), Soil and Water Assessment Tool (SWAT), Environmental Policy Integrated Climate (EPIC), Limburg Soil Erosion Model (LISEM) are available to assess soil erosion, they are applicable only to particular areas or designed for specific applications [SCHMIDT (ed.) 2000]. Because slope gradient is one of the important factors affecting soil erosion intensity at smaller scales [FOX, RORKE 1999; LIU et al. 2006; JÓZEFACIUK, JÓZEFACIUK 1995; ZIEMNICKI, MAZUR 1955], slope profile needs to be carefully considered in this study. WEPP model has a slope editor capability and its main advantage is that it can be extrapolated to conditions for which field testing is not feasible. The WEPP model is intended for modelling soil loss and sediment yield which is significantly influenced by channel processes and slope gradient. The recommended maximum field size allows it to be available for land consolidation investigations at sloping lands.

Although modelling may not give precise results of simulations reflected the current (actual) soil loss in given field conditions [REJMAN, BRODOWSKI 2010] it can be very useful to simulate different scenarios and configuration of soil protection measures to combat soil erosion [LIU et al. 2013]. The study confirmed that one of the most important recommendations for land consolidation in eroded areas is the design of fields to allow transverse cultivation. However, this may not be enough. To maximize protect the soil from degradation, further protection must be provided. First of all sodding of boundaries is needed. While in flat areas, such balks are not protective and the only ones are clear boundaries between plots, in sloping areas they are an important element in prevention of erosion. In addition to reducing soil losses as a result of the runoff, performed simulations clearly indicate activity towards reducing sediment yield outside slope. This confirms the results of earlier studies [DE BAETS et al. 2006; KONEČNA et al. 2012; KOWALCZYK et al. 2011]. In order to effectively reduce erosion on the entire slope, it is necessary to introduce barriers against concentration of runoff in the upper slopes. In addition to the sodding balks, the best for this purpose seem to be woodlots [PRZEGON et al. 2016; WĘGOREK 2008]. Simulations also indicate how important in this aspect are farmers decisions after consolidation. The use of proper antierosion crop rotation including crops protected soil against erosion in the upper slopes (e.g. alfalfa) can reduce (more than double) both the soil loss and sediment yield.

\section{CONCLUSIONS}

1. The transverse plots layout significantly reduces soil erosion risk compared to the longitudinal system.

2. In addition to the design of transverse layout of parcels during consolidation, further antierosion measures may be necessary to reduce soil loss and sediment yield.

3. In order to minimize soil losses outside the slope, it would be appropriate sodding the boundaries between the newly designed fields already in the post consolidation management.

4. Limitation the amount of erosion over the entire slope requires use of additional protection measures at the upper part of slopes; shelterbelts and antierosion crop rotations may be useful here.

5. The WEPP model can be recommended for Provincial Bureaus of Surveying as a simulation tool to support the development of consolidation projects of lands threatened by erosion.

\section{Acknowledgement}

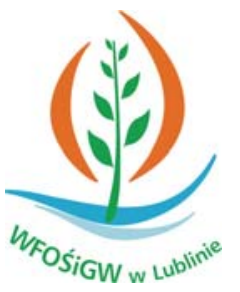

Dofinansowano ze środków

Wojewódzkiego Funduszu Ochrony Środowiska i Gospodarki Wodnej w Lublinie Cofinanced by Voivodeship Fund for Environmental Protection and Water Management in Lublin 


\section{REFERENCES}

BRONSTERT A., VOLIMER S., IHRINGER J. 1995. A review of the impact of land consolidation on runoff production and flooding in Germany. Physics and Chemistry of the Earth. Vol. 20. No. 3-4 p. 321-329.

Chartin C., Evrard O., Salvador-Blanes S., HinSCHBERGER F., VAN OOST K., LEFÈVRE I., DAROUSSIN J., MACAIRE J.J. 2013. Quantifying and modelling the impact of land consolidation and field borders on soil redistribution in agricultural landscapes (1954-2009). Catena. Vol. 110 p. 184-195.

De Baets, S., Poesen, J., Gyssels, G., Knapen, A. 2006. Effects of grass roots on the erodibility of topsoils during concentrated flow. Geomorphology. Vol. 76 p. 5467.

FlanAGAn D.C., LivingSTON S.J., 1995. Water Erosion Prediction Project (WEPP) version 95.7 user summary. NSERL Report No. 11, USDA-ARS National Soil Erosion Research Laboratory. West Lafayette, IN pp. 139.

Fox D.M., RORKE B.B. 1999. The relationship of soil loss by interrill erosion to slope gradient. Catena. Vol. $38 \mathrm{p}$. 211-222.

JABŁOŃSKI T. 2012. Założenia do projektu scalenia obrębu Latyczyn. [Assumptions for the project of consolidation of Latyczyn precinct]. Typescript. Zamość. Wojewódzkie Biuro Geodezji w Lublinie, Pracownia Terenowa w Zamościu pp. 25.

JózeFACIUK A., JÓZEFACiUK Cz. 1995. Erozja agroekosystemów [Erosion of agro-ecosystems]. Warszawa. PIOŚ pp. 138.

JózEFACIUK CZ., WoCH F., JADCZYSZYN J. 1991. Specyfika scaleń na terenach wyżynnych [Specificity of land consolidation of upland areas]. Zeszyty Naukowe AR w Krakowie. Nr 256. Z. 30 p. 15-21.

JÓZEFACIUK CZ., Woch F., TAŁAlaj Z., Nowocień E. 1992. Koncepcja kompleksowego scalania silnie urzeźbionych gruntów wsi Żurawnica woj. Zamość [Concept of complex land consolidation of heavily carved lands of the village Żurawnica, Zamość province]. Zeszyty Naukowe AR w Krakowie. Nr 271. Z. 35 p. 171-179.

KoneČna J., PodHrazska J., TOMAN F. 2012. Efficiency of soil and flood control measures in land consolidations. Acta Universitatis Agriculturae et Silvicultarae Mendelianae Brunensis. Vol. 60. No. 6 p. 161-166.

KORELESKI K. 1987. Ochrona gruntów w pracach scaleniowych na przykładzie obiektów z terenu południowej Polski. W: Nowe tendencje w teorii i praktyce urządzania obszarów wiejskich. Materiały VI Sympozjum [Protection of land in consolidation works on the example of objects from southern Poland. In: New trends in the theory and practice of rural management. Materials VI Symposium]. Zeszyty Naukowe ART Olsztyn, Geodezja i Urządzenia Rolne. Nr 6 p. 33-42.

KowalczYK A., Twardy S., KuŹNIAR A. 2011. Permanent turf grass as the factor alleviating water erosion in the Carpathian Mountains. Journal of Water and Land Development. No. 15 p. $41-51$

LISEC A., PINTAR M. 2005. Conservation of natural ecosystems by land consolidation in the rural landscape. Acta Agriculturae Slovenica. Vol. 85(1) p. 73-82.

LiU S.L., DONG Y.H., Li D., LiU Q., Wang J., Zhang X.L. 2013. Effects of different terrace protection measures in a sloping land consolidation project targeting soil erosion at the slope scale. Ecological Engineering. Vol. 53 p. $46-53$.
LiU S.Y., QIN F.C., Xiang Y.H., LeI F.Y. 2006. Study on the relationship between slope and the amount of soil loss based on WEPP. Journal of Arid Land Resources and Environment. Vol. 20(4) p. 97-101.

Noga K., Pijanowski Z. 1993. Sposób ujmowania i rozwiązywania zagadnień ochrony środowiska $\mathrm{w}$ pracach scaleniowych [The method of recognizing and solving environmental issues in the work of land consolidation]. Prace Naukowe. PW. Ser. Geodezja. Z. 32 p. 81-89.

PAŁYS S., MAZUR A. 2015. Erozja wodna gleb w wybranych zlewniach Wyżyny Lubelskiej w świetle wieloletnich badań [Water erosion of soils in selected basins of $\mathrm{Lu}-$ blin Upland on the basis of long-term research]. Wiadomości Melioracyjne i Łąkarskie. Nr 4 p. 167-172.

Pieri L., BitTelli M., Wu J.Q., Dun S., Flanagan D.C., Pisa P.R., Ventura F., Salvatorelli F. 2007. Using the water erosion prediction project (WEPP) model to simulate field-observed runoff and erosion in the Apennines mountain range. Italy. Journal of Hydrology. Vol. 336 p. 84-97.

PRZEGON W., RYBICKI R., OBRoŚlAK R., GABRYSZUK J., KRÓL Ż. 2016. The concept of phytomelioration of open agricultural landscape on example of Wola Idzikowska village. Journal of Ecological Engineering. Vol. 17(2) p. $163-168$.

REJMAN J., BRODOwSKI R. 2010. Ocena erozji wodnej gleby lessowej na uprawach buraka cukrowego i pszenicy jarej na podstawie badań poletkowych [Evaluation of water erosion under sugar beet and spring wheat on loess soil on runoff plots]. Prace i Studia Geograficzne. T. 45 p. $215-228$.

SCHMidT J. (ed.) 2000. Soil erosion. Application of physically based models. Berlin-Heidelberg. Springer-Verl. pp. 318.

SHUAI Y.I.N., ChaO-Fu W.E.I. XIN-YUE Y., You-Jin L.U.O. 2011. The ecological compensation of land consolidation and its evaluation in hilly area of Southwest China. Energy Procedia. Vol. 5 p. 1192-1199.

Singh R.K., PANDA R.K., SATAPATHY K.K., NGachan S.V. 2011. Simulation of runoff and sediment yield from a hilly watershed in the eastern Himalaya, India using the WEPP model. Journal of Hydrology. Vol. 405(3/4) p. 261-276.

Weatheronline.pl undated. Archiwalne dane o pogodzie na świecie [Archival weather data in the world] [online]. [Access 10.04.2017]. Available at: www.weatheronline. $\mathrm{pl} /$ weather/maps/forecastmaps?LANG=pl\&CONT=plpl $\& \mathrm{R}=151$

WĘGOREK T. 2008. Biologiczne metody zmniejszania zagrożenia gleb erozją wodną (fitomelioracje). W: Problemy erozji gleb w procesie przemian strukturalnych na obszarach wiejskich [Biological methods to reduce the risk of soils from water erosion (phytomelioration. In: Problems of soil erosion in the process of structural changes in rural areas]. Studia i Raporty IUNG-PIB. $\mathrm{Nr}$ 10 p. $123-148$.

Woch F. 1994. Spodziewane efekty melioracji przeciwerozyjnych w procesie kompleksowego scalania gruntów [Expected effects of antierosion melioration in the process of comprehensive land consolidation]. Roczniki AR w Poznaniu. Nr 266. Melioracje i Inżynieria Środowiska. T. 14 p. 357-365.

Woch F. 2008. Urządzenioworolne metody zmniejszania zagrożenia erozyjnego gleb [Agricultural hardware methods for reducing risk of soil erosion]. Studia i Raporty IUNG-PIB. Nr 10 p. 79-101. 
Woch F., JózefACiUK Cz. 1996. Program kompleksowego urządzania obszaru gminy Wąwolnica. W: Ochrona agroekosytemów zagrożonych erozją [Program of comprehensive management of the Wąwolnica municipality area. In: Protection $\mathrm{f}$ agroecosytems threatened by erosion]. Puławy. IUNG K(11/1) p. 277-289.

Woch F., JózeFACIUK Cz. 1999. Koncepcja kompleksowego scalania gruntów na obszarze chronionym o zróżnicowanej rzeźbie [The concept of a comprehensive land consolidation in a protected area with varied sculpture]. Pamiętmik Puławski. Z. 119 p. 65-81.

ZIEMNICKI S. 1967. Melioracje przeciwerozyjne [Antierosion meliorations]. Warszawa. PWRiL pp. 360.

ZIEMNICKI S., MaZur Z. 1955. Przekrój zbocza jako odzwierciedlenie erozji gleb [Cross-section of the slope as a reflection of soil erosion]. Annales UMCS. Vol. 10. Sect. E p. $77-152$.

\section{Roman RYBICKI}

Ocena skutków scalenia gruntów we wsi Latyczyn w aspekcie ochrony gruntów przed erozją w skali stoku

\section{STRESZCZENIE}

Erozja wodna gleb jest ważnym zagadnieniem gospodarczym, silnie pogarszającym stan środowiska, wymagającym działań zaradczych. Badania miały na celu ocenę przeciwerozyjnych efektów zmiany układu działek z wzdłużstokowego na poprzecznostokowy w wyniku scalenia gruntów. Oceniono też słuszność pozostawienia nowo wytyczonych granic działek bez zastosowania żadnych środków przeciwerozyjnych (np. zadarnień). W tym celu dokonano dodatkowej symulacji zastosowania różnych środków przeciwerozyjnych z wykorzystaniem modelu WEPP (ang. Water Erosion Prediction Project). Badania wykazały, że poza zaprojektowaniem w trakcie scalenia układu poprzecznostokowego niezbędne mogą być dalsze środki przeciwerozyjne, aby ograniczyć erozję gleby i jej wynoszenie poza obszar stoku. Aby zminimalizować straty gleby poza stok, należałoby już w trakcie zagospodarowania poscaleniowego zadarniać granice między nowo zaprojektowanymi polami. Ograniczenie rozmiarów erozji na całym stoku wymaga stosowania dodatkowych umocnień w górnych partiach zbocza, np. zadrzewień śródpolnych oraz płodozmianów przeciwerozyjnych. Model WEPP może być rekomendowany Wojewódzkim Biurom Geodezji jako narzędzie wspomagające opracowanie projektów scalania gruntów na terenach zagrożonych erozją.

Słowa kluczowe: erozja gleby, model WEPP, modelowanie erozji, scalenia gruntów, tereny wyżynne 